\title{
Gender as a recruitment criterion in the parliamentary political elite of Latvia (1993-2016)
}

\author{
Lelde Metla-Rozentale* \\ Rīga Stradinsš University, Latvia
}

\begin{abstract}
The globalization process has transformed substantially understanding of the issue of border. Revising borders is also seen in political science - in the area of political elite recruitment. Recruitment criteria and their importance are changing, including the importance of gender. In 1981 the United Nations General Assembly adopted the Convention on the Elimination of All Forms of Discrimination Against Women, which provides equal rights of genders in the political elite, the so-called "mirror representation", i.e., in the political elite men and women should be represented proportionally according to their number in society [4]. It should be particularly stressed that the purpose of "mirror representation" is not only to ensure equal rights of genders, but first of all to improve the quality of politics. As soon as Latvia regained its independence in 1990, the complicated process of formation (recovery) of the democratic governance model started. In 1993 the first parliamentary elections were held, and by 2016 elections for eight parliamentary terms had been held [3]. In view of the complex political history of Latvia, it is interesting and important to clarify the role of gender in the Latvian parliamentary political elite recruitment process - what correlations can be observed with regard to the male and female share in the parliament during the period from 1995 till 2016, and the extent to which it complies with the sex ratio breakdown of the society.
\end{abstract}

Key words: political elite recruitment, recruitment criteria, "mirror representation" - proportional representation of genders in the political elite.

\section{Introduction}

One of the fundamental principles of democratic governance forms is power sharing. Idea of the power sharing emerged in the work of French Enlightenment philosopher Charles Louis de Montesquieu (Charles-Louis de Second at, baron de La Brède et de Montesquieu, 1689-1755) who described it in the work The Spirit of the Laws (De l'esprit des loix) published in 1748. According to the theory of C.L. de Montesquieu, by dividing State power between the authorities of executive, legislative and judicial power and ensuring that each of these authorities have the opportunity to act independently political freedom is ensured [19]. Therefore, the particular quality of these three powers predetermines stability and development of the democratic political regime.

The legislature, executive and judiciary power do not only comprise a theoretical concept or construction; each of these powers is specifically implemented by institutions while these institutions are formed by people.

\footnotetext{
* Corresponding author: lelde.rozentale@rsu.lv
} 
This research article is devoted to one of the powers - the legislative power. Its main task is to determine strategic objectives for the development of society. In order to achieve these objectives, representatives of the legislative power create the appropriate political and legal means by issuing binding legal norms. The representatives of the legislative power implement also other functions, for example, constitute the executive and the judiciary powers at higher institutions, carry out supervision of the government, perform executive activities, as well as other activities within its competence [18]. Activities, carried out in this branch of power, are aimed at representation of concerns of the society as a whole, including equal representation of both genders in any area and activities.

The actors involved in the process of implementation of the particular national legislation are provided for in the Constitution. In most cases, the legislative power in the State is delegated to the members of parliament and the nation. In the Republic of Latvia (hereinafter - LV), in accordance with Article 64 of the Constitution the legislative power belongs to the Parliament and also to the nation, and is implemented by the procedures and in the extent determined by the Constitution [24]. Legislative power is delegated by means of electoral process, and thus it is considered to be delegated collective power of representation, and the Parliament is the institution of nation representation.

The Constitution of the Republic of Latvia provides that the Saeima shall be composed of one hundred representatives of the nation who shall be elected for four years in general, direct, secret and proportional elections. The rights to vote in the parliament election are granted to citizens of Latvia, who have attained 18 years of age on the Election Day. Any full-fledged Latvian citizen who on the Election Day is older than 21 years may be elected to be a member of the Saeima. Parliamentary election procedures are determined by the Saeima Election Law. Parliamentary election process is determined and conducted by a permanent and elected State body - the Central Election Commission [23].

This short description of the structure of Latvian legislative power shows that it is formed by the Parliament (Saeima) while this institution is comprised by its members - the parliamentary political elite.

The central factor of the power and influence of political elite (the elite power) is the recruitment of elite or selection of candidates [17]. In the long-term research process the researchers have identified the optimal criteria, or the ideal model, of recruitment criteria which is considered to be the basis of the quality of work and efficiency of the political elite in the framework of a democratic political authority [16, 25, 26, 31]. People, who implement the recruitment process, obtain a set of qualifications to be required from a potential member of the political elite, and the opportunity of that person to enter the area of the political elite is directly related to the person's ability to offer the required work.

When the Latvian independent statehood was restored, there was a need for political elite able to work in accordance with the new, democratic governance model, however, at that time questions about the qualities that could be required from the candidates of the political elite as well as persons whose competency included implementation of the recruitment process, were not yet answered. Due to the political history of Latvia, and 50 years of being part of the Union of Soviet Socialist Republics, unfamiliarity with the democratic practices regarding recruitment requirements and their satisfaction, as well as limited professional qualifications of the political elite was imminent, and inevitable.

In 27 years since the restoration of independence, Latvia has experienced very rapid growth and development in both the public and private sectors. There has been a steady economic development of Latvia, driven by the economic and structural reforms, as well as accession process to the EU and NATO. However, during this period, population's distrust in the Latvian members of Parliament remained consistently high - in $200471 \%$ of the population expressed their opinion that they did not trust the Parliament, and in $201575 \%$ 
of the population expressed the same opinion [27]. The surveys show that the majority of Latvian society considers politicians as incompetent and incapable of problem solving.

This reveals a situation where it is obvious that despite the significant economic, political and other changes, and attempts to move closer to the traditional Western democratic political practice by the goals and aspirations, the recruitment process of Latvian political elite has not actually come closer to the ideal model of the recruitment criteria.

\section{Material and methods}

As the title of the article indicates, the focal point of this research is the parliamentary political elite including member recruitment analysis, and focusing on one specific recruitment criterion, namely gender. On the basis of the research carried out by the author of this research article, importance of the gender role in the recruitment of the Latvian parliamentary political elite process was clarified - what correlations can be observed with regard to the male and female share of the Parliament, and to what extent it complies with the gender apportioning of society. The obtained results were compared with situation in the Western Europe, the Northern Europe (Scandinavia), and the world at large. At the start of the study, the hypothesis was - the number of women in the Parliament in Latvia in not proportional to their number in society, and this trend is much more pronounced in Latvia than in the Western Europe and Scandinavia.

It may be considered that the Latvian parliamentary political elite started its existence on November 18, 1918 when the Republic of Latvia was proclaimed. Its first legislature was the National Council established on 17 November 1918 in the result of agreement of 40 members belonging to eight Latvian democratic political parties in cooperation with representative of the Latgale Land Council. Due to the particular political conditions, elections at that time were not possible. The National Council existed until 30 April 1920. The first popularly elected legislature in Latvia was the Constitutional Assembly whose elections were held in 1920. Work, initiated by the Constituent Assembly in the legislative area, was continued by Saeimas - 1st Saeima (1922), 2nd Saeima (1925), 3rd Saeima (1928), 4th Saeima (1931). As a result of coup d'état of 15 May 1934, work of 4th Saeima was terminated, and functions of the Saeima were taken over by the Cabinet of Ministers [3].

Elections of the next, 5th Saeima, took place only after more than 60 years - after the restoration of independence of the Latvian State in 1993. Elections of the 6th Saeima were held in 1995, 7th -1998 , 8th -2002 , 9th -2006 , 10th $-2010,11$ th -2011 . Currently the legislative functions are implemented by 12th Saeima elected on 14 October, 2014 [22]. This situation indicates that the existence of the Latvian parliamentarian political elite may be divided into two periods, namely from 1918 to 1934, and from 1993 to the present. For the purposes of this research, the period from the restoration of independence of the Latvian state in 1993 - underlying existence of the Latvian parliamentarian political elite of the 5th-12th Saeimas (1993-2016) - is explored. Such a division of the subject is justified because of the long break in the democratic parliamentary practice due to which it is not possible to talk about succession in this practice and a common evolutionary process in the period between 1918 and 2016. Each of those two periods is fundamentally different in the sense of form and content so the research approach should be particular for each of the periods.

The sources used for obtaining the research data:

- Primary statistical data on gender representation in the lists of candidates formed by the political parties before the parliamentary elections compiled by the Central Election Commission of Latvia $[5,7,9,11,12,14]$; 
- Primary statistical data on gender representation at the Parliament after each election compiled by the Central Election Commission of Latvia [6, 8, 10, 13, 15, 21];

- Data on gender representation in relation to different parliamentary positions in Latvia compiled by the author of this research article [20];

- Data on gender proportional distribution in different countries of the world compiled by the World Bank [30];

- Primary statistical data on gender representation at the world's national parliaments compiled by the Inter-Parliamentary Union (IPU) [28].

\section{Results}

Having evaluated the political practice of democratic states, the author of this article concluded that in the parliamentary political elite recruitment process, 3 stages can be identified: the first stage comprises selection of candidates and their inclusion in the list of a party, the second stage - recruitment implemented by the electorate in the election process, and the third stage - the processes, where only a limited number of persons are recruited for various parliamentary positions out of the circle of all elected persons, and hence are considered to be influential parliamentary political elite members.

The first stage of recruitment, which is selection of candidates and their inclusion in the list of a party, is a comparatively formalized process. The recruiting process most often is carried out by the party elite, regional representatives, fraction, interest group, or party leader. Recruiting takes place in accordance with the intrinsic normative acts of the party, informal norms and practical assessment of the situation (aspirations of the electorate, and possibilities of the party). It should be noted that there are not only the formal, officially appointed for their position recruitment makers, but also various other participants playing essential role, such as supporters and sponsors. Decision-making process in the party itself depends on the degree of institutionalization and centralization. In the second stage of the recruitment, the electorate make their choice through the election procedures. However, the third phase of recruitment is much less open and transparent - recruitment of the persons to the various parliamentary posts from the inner circle of those elected to the parliament. The research focused on all three stages and how they affect proportional representation of the gender in respect to the Latvian parliamentary political elite.

The survey results show that the gender breakdown of the Latvian population in the period from 1993 to 2016 was equal and constant. Approximately 54\% of the total population are women, and 46\% - men, as shown in Fig. 1 [2].

Comparing these indicators with those of the other countries, it can be concluded that the proportion between genders fluctuates from 33.6\% women/66.4\% men in Asia and Africa region to $54.1 \%$ women $/ 45.9 \%$ men in the Eastern Europe region [29]. Latvia, having the aforementioned indicators, stands out as the country with the highest proportion of women in the society.

According to theoretical guidelines, in order to ensure the qualitative political processes and equal representation of the interests of all members of society in the political sphere, men and women in the political elite should be represented in proportion to their share in the society. How is it in reality? To reflect the actual situation, Fig. 2 presents aggregated data on the female and male representation proportion in the Latvian Parliament $[6,8,10,13,15,21]$. The results of the research indicate that over the period between 1993 and 2016 the average share of females in the parliamentary elite of Latvia was $18.2 \%$ of the total number of members of the elite (fluctuating between 9 and $25 \%$, with a trend to decrease over the last two years). 


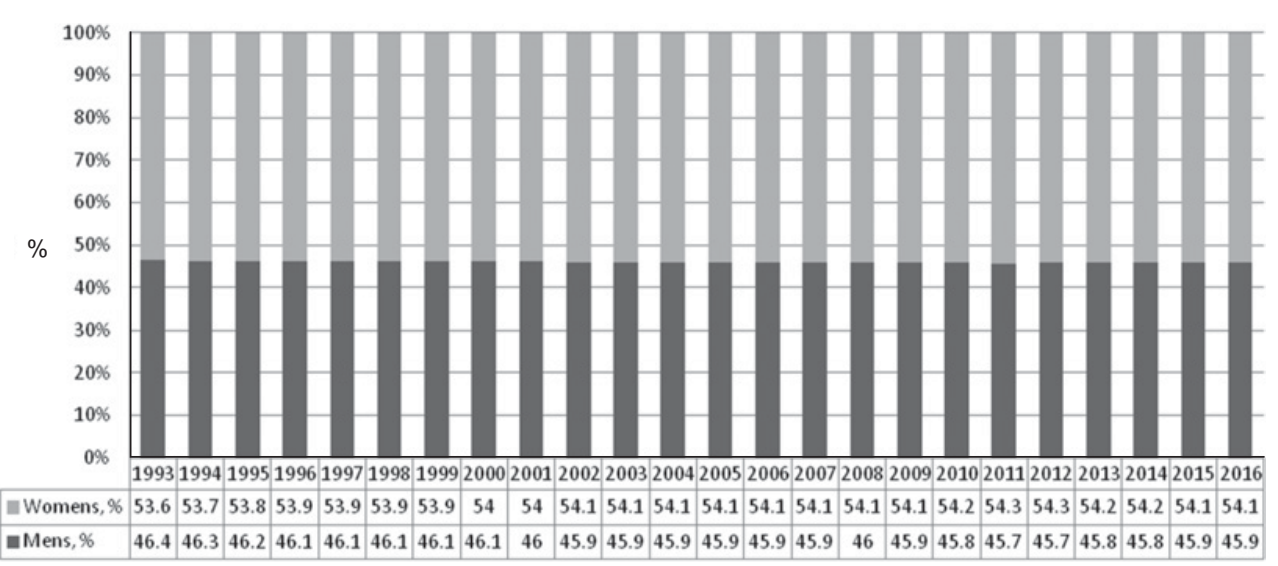

Fig. 1. Male and female shares in the society, LV.

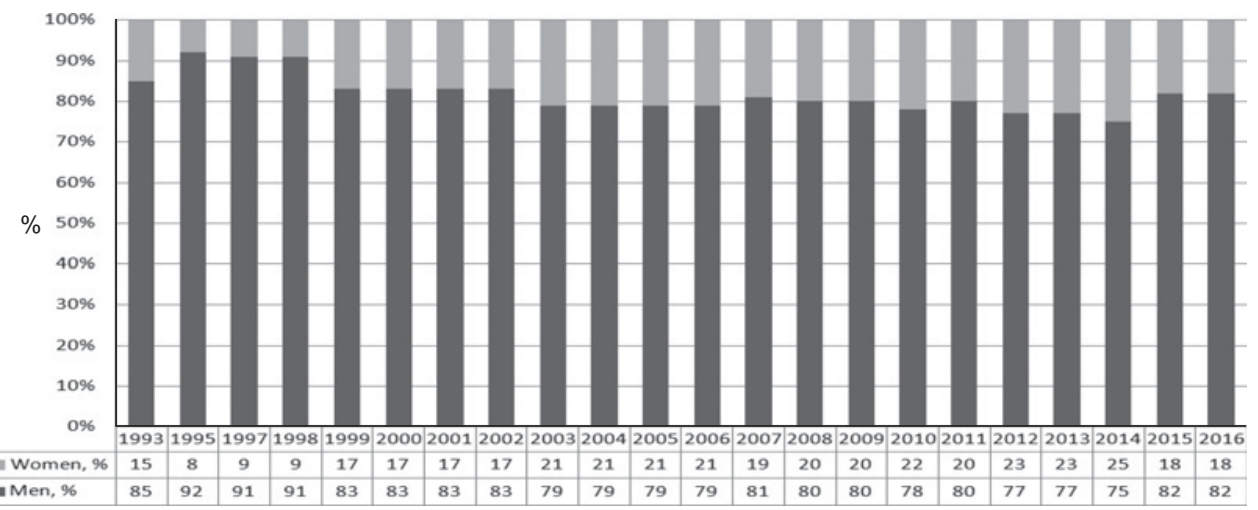

Fig. 2. Male and female proportion in the parliament, LV.

It can be concluded that the gender breakdown of the Latvian society is not reflected by gender representation in the Parliament. Comparing the data it is obvious that there are three times less women in the Latvian Parliament than in the general population.

In order to compare the situation in Latvia with other countries, a comparative analysis was carried out, and the results are shown in Fig. 3. The acquired data show that in Western Europe the average share of females in the parliamentary elite was $17.7 \%$, and in Northern Europe (Scandinavian countries) it was $40.2 \%$, whereas the average indicator in the world was $16.9 \%$ [28]. In its turn, the share of females in society in the world is averagely $49.6 \%$ of all population, which indicates a significant disparity between women's representation in society and the political elite $[28,30]$.

The acquired data confirm that the situation in Latvia does not differ from the situation in other countries of the world as the discrepancy between the gender breakdown of society and its proportional representation in the political elite is not particularly unique to Latvia - it is equally seen in other countries.

Looking for the rationale behind such discrepancy, the academic literature offers the following explanation: the role of the gender in the recruitment process is determined by the voters' demand [25]. The main statement on motivation in the process of party's formation of the candidate list, considering gender representation, is reluctance to lose voters' support, which means that it is believed that voters prefer to vote for male candidates, and if the party's candidate list would include more women, the party, according to such speculations, might 


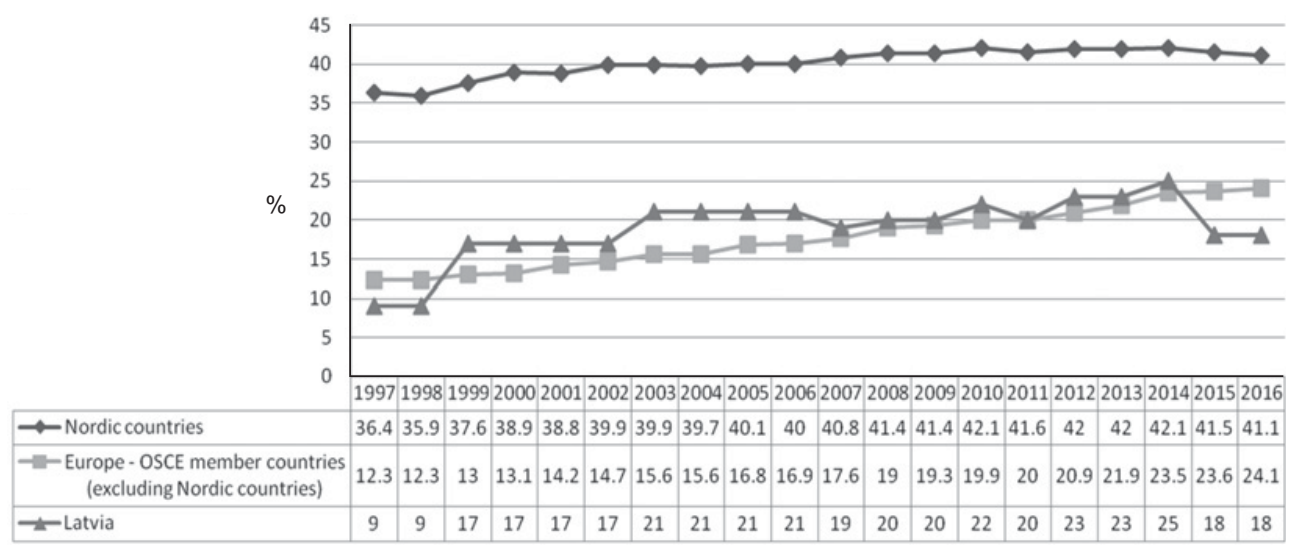

Fig. 3. Women's representation in parliaments - regional averages.

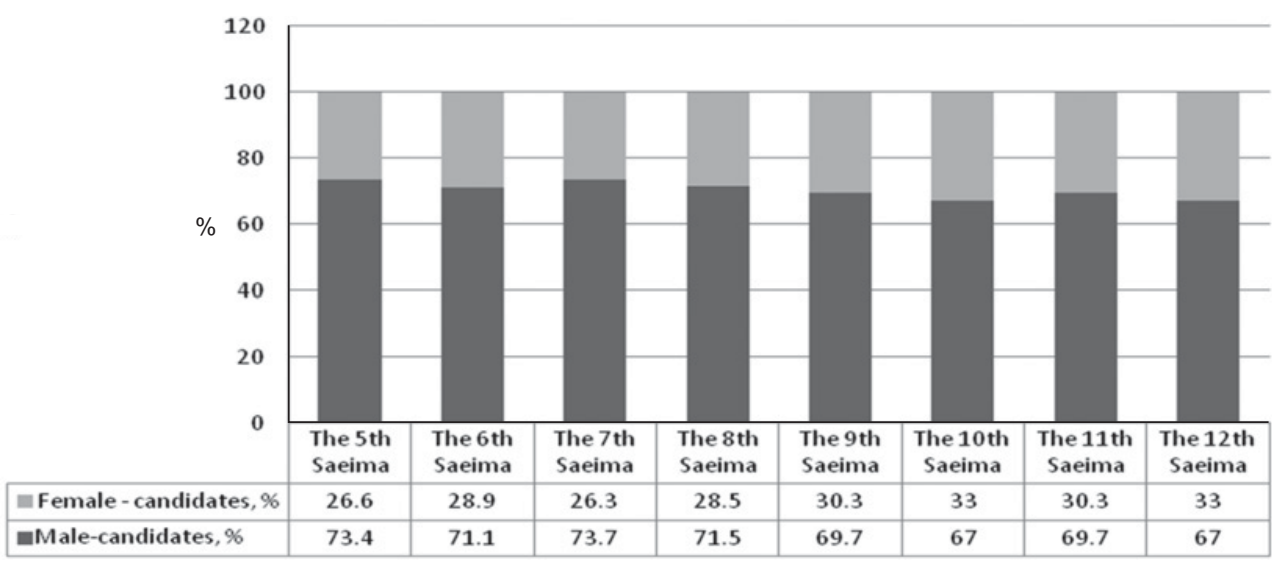

Fig. 4. Male and female shares in lists of candidates, LV.

lose the voters' support. However, in the previous research it could not have been possible to obtain conclusive evidence for the proposition that the lesser involvement of women in politics is directly related to the reluctance of political parties to lose votes, and that because of a woman in a party it would have fewer supporters. Discrimination is one of the most difficult things to prove, and at the same time it is among the easiest and misleading explanations of various situations [25].

Taking into account the facts described above, further in the research data on inclusion of women and men in the party lists of candidates were analysed. As shown in Fig. 4, the total number of candidates on the average amounts to $30 \%$ of women and $70 \%$ of men $[5,7,9,11,12,14]$.

The figures show that the number of women included in the candidate lists is 1.8 times smaller than the number of women in the general population; at the same time, there are 1.6 times more women in the lists than in the Parliament. This leads to the conclusion that, perhaps, the Latvian voters prefer to vote for men, and the theoretical assumption on the existence of this fact is true. This fact, in turn, can affect the behaviour of political parties, the process of developing election candidate lists and make them opt for a disproportionate gender representation in the lists, thereby seeking to attract the support of voters. 


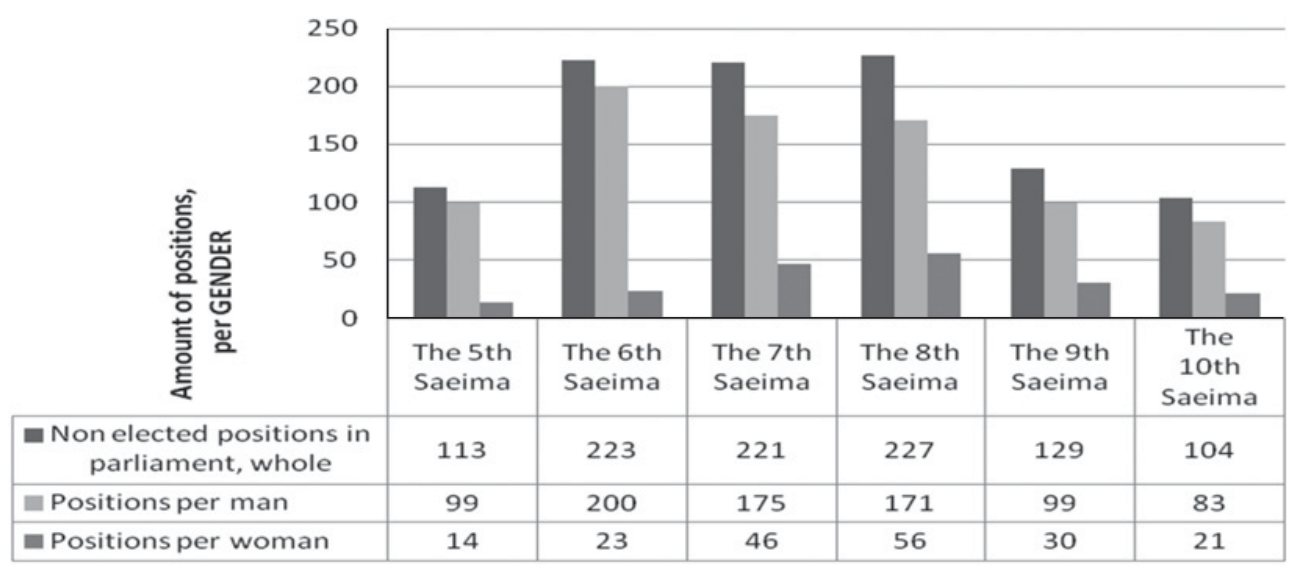

Fig. 5. Male and female shares in lists of candidates, LV.

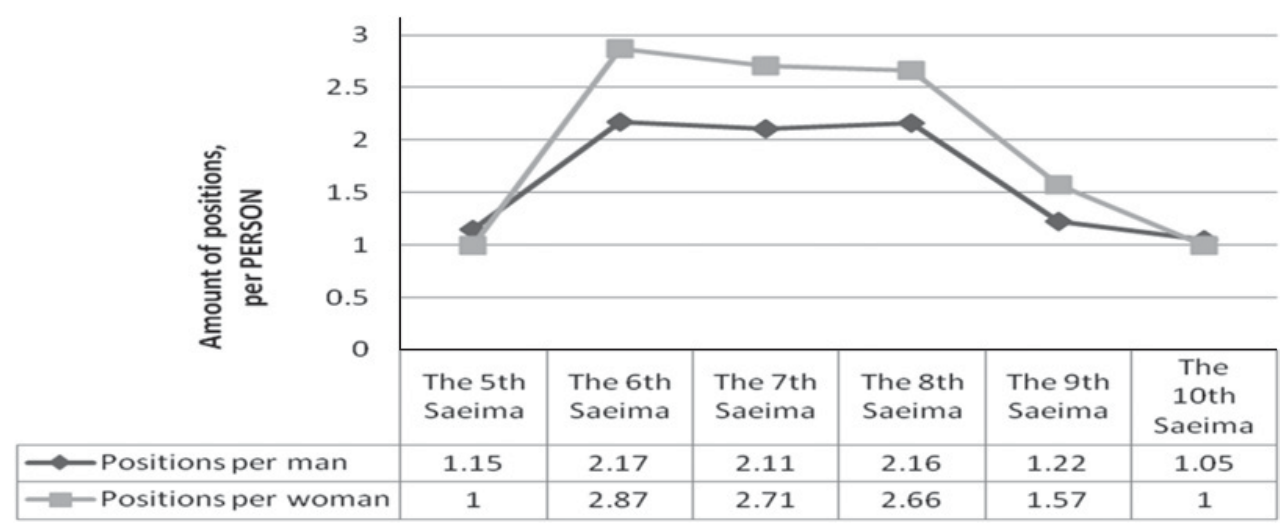

Fig. 6. Gender representation in non-elected positions in parliament, LV.

The study further focuses on the third phase of recruiting - the implemented recruitment of persons elected into the Parliament for different parliamentary seats. The expression "parliamentary seats" refers to the following seat positions - the Saeima Speaker, Saeima Deputy Speaker, Secretary, Deputy Secretary, Chairman of the Fraction, Deputy Chairman of the Fraction, Fraction Secretary, Chairman of the commission/subcommittee/special commission, Deputy Chairman of the commission/subcommittee/special commission, Secretary of the commission/subcommittee/special commission, as well as Members of the Cabinet (ministers of different fields, prime ministers), which have been recruited among the members of the Parliament.

Figure 5 illustrates the total number of parliamentary seats during the 5th-10th term of the Saeima, as well as their distribution between men and women [20].

As it can be seen, the number of parliamentary positions in various convocations of Saeima has been rather different, and also the number of representatives of both genders elected to the Saeima has been different. $[6,8,10,13,15,20]$ Therefore, in order to properly provide the ratio of gender representatives holding the aforementioned positions, the numeric value showing posts per person was calculated for each of the parliamentary terms. This is visually reflected in Fig. 6.

The results of this calculation show that within Saeima, in the processes of recruitment of the persons for parliamentary positions, proportional gender representation has been fully 


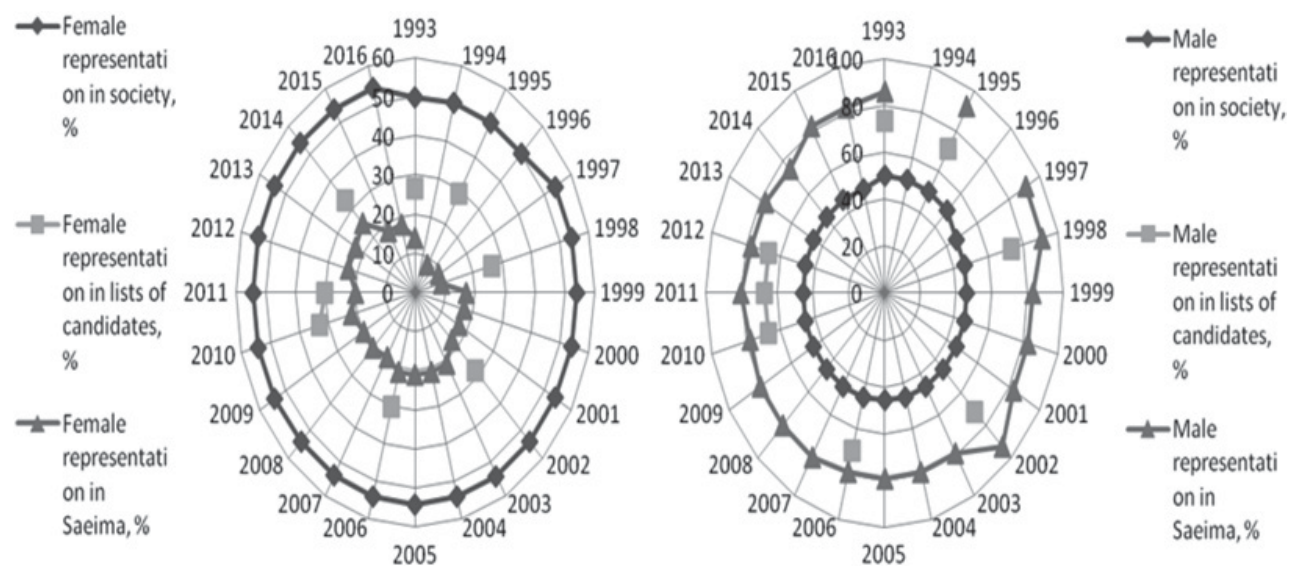

Fig. 7. Comparison of female and male representation, LV.

maintained - each elected person, regardless of their gender, has held the same number of positions.

However, the research shows inequality between gender representation in society and the political elite, which has a negative impact on women's opportunities to participate in the State governing processes $[2,6,8,10,13,15,20]$. The left side of Fig. 7 shows a significant difference between the proportion of women in the society and the number of women on the candidate lists of the parties, and even less number of the women elected to the Parliament. On the opposite, the right side shows a completely different situation related to representation of men in the Parliament and scope of their recruitment for various parliamentary positions, which significantly exceeds the number of men in the society.

Thus, in spite of the relatively equal shares of both genders in the Latvian society, in the process of recruitment of the parliamentary political elite in the period from 1993 to 2016 both genders had not been recruited equally-in accordance to their proportion in the society.

\section{Conclusions}

In the political elite of Latvia, the number of recruited women is 2.9 times smaller than would be necessary to ensure proportional representation of both genders.

A similar situation can be observed in the countries of Western European (as shown by the data analyzed in the research), where the number of women in the parliamentary elite is 2.8 times smaller than in the society overall.

Moreover, based on the summary of the data of all 191 countries of the InterParliamentary Union it may be concluded that the number of women in parliaments is 2.9 times smaller than in the countries overall.

A particular exception among all countries is Northern Europe (Scandinavian countries), where almost a complete conformity is ensured between the gender breakdown in society and in the political elite.

Analysis of the situation shows that it is not a local - national or regional - problem typical for post-Soviet countries but an overall trend that is also seen in Latvia.

In the lists of candidates of the parties who enter Latvian parliamentary elections 1.8 times less women have been included in comparison to the number that would be necessary to ensure proportionally of the public representation from the gender perspective. 
The society, when voting for certain candidates in the elections, recruited about 1.6 times less women to the Parliament than would have been possible taking into account the number of women in the lists of candidates. This shows the society's intentional or unintentional discriminatory treatment in respect of women's implementation of parliamentary representation.

As a positive aspect, it should be emphasized that after the elections, in the processes of recruitment for parliamentary positions within the Parliament, an absolute proportional gender representation has been maintained - each person elected regardless of gender ranks equal, meaning that persons of both genders have the same number of posts.

However, the process of the recruitment of Latvian political elite does not provide proportional representation of men and women in the Parliament according to their share in the society, and principle of "mirror representation" is not implemented, which not only contributes to gender inequality but also has an adverse impact on the quality of politics.

The legal quota system could be used as one of the possible tools for improving the situation [1]. Many Western and Northern European countries, as well as neighbouring Lithuania, have introduced the principle of voluntary party quotas, which recommends that each political force establishes a minimum level of involvement of women, even if implementation of this voluntary principle does not ensure the desired effect - adequate participation of women. Therefore, an alternative could be that women's quotas were determined as obligatory through legislation that can predetermine mandatory women's involvement indicator in respect of their inclusion in the deputy candidate lists, and also election to the Parliament - the reserved seats for women, thus ensuring implementation of the "mirror representation" principle in practice. Of course, there is a disputable question will obligatory quotas provide the desired effect.

\section{References}

[1] Atlas of Electoral GenderQuotas, http://www.quotaproject.org/aboutQuotas.cfm (20.01.2017)

[2] Centrālā statistikas pārvalde, Sievietes un vīrieši Latvijā, 2016, http://www . csb.gov.lv/sites/default/files/nr_13_sievietes_un_viriesi_latvija_ 2016_16_00_lv_en.pdf (20.01.2017)

[3] Centrālā vēlēšanu komisija, 5.,6.,7.,8.,9.,10.,11..12. Saeimas vēēěšanas, https:// www.cvk.1v/pub/public/27427.html

[4] Convention on the Elimination of All Forms of Discrimination against Women, http://www . un.org/womenwatch/daw/cedaw/text/econvention.htm

[5] CVK, 10.Saeima. Statistika par deputātu kandidātiem, https://www.cvk.lv/cgibin/wdbcgiw/base/komisijas2010.cvkand10.sak

[6] CVK, 10.Saeima. Statistika par ievēlètajiem deputātiem. https://www.cvk.lv/ cgi-bin/wdbcgiw/base/komisijas2010.galrez10.statko

[7] CVK, 11.Saeima. Statistika par deputātu kandidātiem, https://www.cvk.lv/cgibin/wdbcgiw/base/komisijas2010.cvkand11. sak

[8] CVK, 11.Saeima. Statistika par ievēètetajiem deputātiem, https://www.cvk.1v/ cgi-bin/wdbcgiw/base/Saeima11.galrez11. statko

[9] CVK, 12.Saeima, Statistika par deputātu kandidātiem, http://sv2014. cvk.lv/saraksti/

[10] CVK, 12.Saeima, Statistika par ievēlētajiem deputātiem, http://sv2014.cvk.lv/ ieveletie_saraksti/

[11] CVK, 7.Saeima, Statistika par deputātu kandidātiem, https://www.cvk.1v/ cgi-bin/wdbcgiw/base/base.cvkand.otra 
[12] CVK, 8.Saeima, Statistika par deputātu kandidātiem, https://www.cvk.lv/ cgi-bin/wdbcgiw/base/sae8dev.cvkand . otra

[13] CVK, 8.Saeima, Statistika par ievēètajiem deputātiem, https://www.cvk.lv/ cvkserv/sa8/Statistika8.pdf

[14] CVK, 9.Saeima, Statistika par deputātu kandidātiem, https://www.cvk.1v/ cgi-bin/wdbcgiw/base/saeima9.cvkand9. sak

[15] CVK, 9.Saeima, Statistika par ievēlētajiem deputātiem, https://www.cvk.1v/ cgi-bin/wdbcgiw/base/saeima9.GalRezS9.vis

[16] D. Marvick, Political Recruitment and Careers, In International Encyclopedia of the Social Sciences, edited by David Sills (Macmillan, New York, 1968), pp. 273-292

[17] G. Parry, Political elites, Essex: European Consortium for Political Research Press 30 (2005)

[18] I. McLean, The Concise Oxford Dictionary of Politics, edited. (Oxford University Press, New York, 1996), pp. 280-281, 359-360

[19] I. McLean, The Concise Oxford Dictionary of Politics, edited. (Oxford University Press, New York, 1996), pp. 448-449

[20] L. Metla-Rozentāle, Doctoral thesis, Parliamentary political elite recruitment in Latvia after independence (to be published)

[21] Latvijas Republikas Saeima, 5.,6.,7..Saeima.Statistika par ievēèetajiem deputātiem, http://www.saeima.lv/lv/par-saeimu/likumdeveju-vesture (20.01.2017)

[22] Latvijas Republikas Saeima, Likumdeveju vēsture, http://www.saeima.lv/lv/ par-saeimu/likumdeveju-vesture (20.01.2017)

[23] Latvijas Republikas Saeima, Saeimas vēlēšanas, http://www.saeima.lv/lv/ par-saeimu/saeimas-velesanas (20.01.2017)

[24] Latvijas Republikas Satversme, http://likumi.lv/doc.php?id=57980 (20.01.2017)

[25] P. Norris, J. Lovenduski, Political recruitment: Gender, race, and class in the British Parliament (Cambridge University Press, Cambridge, 1995), pp. 93-182

[26] R.D. Putnam, The Comparative Study of Political Elites (Prentice-Hall, New Jersey, 1976), pp. 57-65

[27] Standard Eurobarometr 84, Autumn 2015, Public opinion in European Union, http://ec.europa.eu/COMMFrontOffice/publicopinion/index.cfm/ Survey/getSurveyDetail/instruments/STANDARD/yearFrom/1986/yearTo/ 2017/surveyKy/2098 (20.01.2017)

[28] The Inter-Parliamentary Union (IPU), Womens in National Parliaments, http: //www.ipu.org/wmn-e/world.htm (20.01.2017)

[29] The World Bank, Gender statistics, http://data.worldbank.org/datacatalog/gender-statistics (20.01.2017)

[30] The World Bank, Population, female (\% of total), http://data.worldbank.org/ indicator/SP.POP.TOTL.FE.ZS (20.01.2017)

[31] Л. Ионин, Социология культуры: путь в новое тысячелетие, Москва: Логос 